\title{
Comparative Clinicopathological Study of Salmonellosis in Integrated Fish-Duck Farming
}

\author{
Anwaar M. El-nabarawy ${ }^{1}$, Mohamed A. Shakal ${ }^{2}$, Abdel-Haleem M. Hegazy ${ }^{3}$ and Mohamed M. Batikh ${ }^{4}$ \\ ${ }^{1}$ Poultry Disease Department- Faculty of Veterinary Medicine-Cairo University, Egypt \\ ${ }^{2}$ Poultry Disease Department- Faculty of Veterinary Medicine-Cairo University, Egypt \\ ${ }^{3}$ Poultry Disease Department Animal Health Research Institute-Kafr El-Sheikh Provisional Lab, Egypt \\ ${ }^{4}$ Poultry Disease Department Animal Health Research Institute-Kafr El-sheikh Provisional Lab, Egypt \\ "Corresponding author’s Email: anwaar.elnabarawy@gmail.com; ORCID: 0000-0003-1618-6842
}

Received: 13 Feb. 2020

Accepted: 23 Mar. 2020

\begin{abstract}
Poultry litter is used in fish farms as fertilizer thus integrated fish-duck farming is common in some areas of Egypt. Salmonella bacteria may be present in poultry litter and contaminate fish ponds and infect duck farms. To investigate incidence and prevalence of Salmonella infection in integrated duck-fish farms, 50 litter samples, 200 cloacal swabs from integrated duck farms, 60 liver samples from integrated duck farms and 69 water samples from the fish pond were collected. Results revealed the isolation and identification of 19 Salmonella spp. belonging to 14 different serotypes (4 isolates from litter, 2 isolates from fish pond water, 8 isolates from cloacal swabs of ducks and 5 isolates from ducks liver). Fifty, one-day-old Pekin ducks were experimentally infected with five chosen Salmonella serotypes (S. Bargny, S. Tshingwe, S. Uganda, S. Kentucky, and S. Enteritidis). The results from experimental infection revealed clinicopathological findings including degeneration and necrosis in the liver, lymphoid depletion and macrophage infiltration in the spleen and enteritis. Mortality ranged from $28.6 \%$ in S. Bargny, S. Enteritidis and $S$. Kentucky and increased to $42.9 \%$ in $S$. Uganda and reached up to $100 \%$ in S.Tshingwe. Body weight gain decreased by $16 \%$ in $S$. Uganda and exceeded to $23.9 \%$ in $S$. Kentucky and decreased by $31 \%$ in S. Bargny and S. Enteritidis as compared to the control group. Feed conversion ratio was recorded and ranged from 5.1, 5.11, 4.98, 5.15 and 4.02 in S. Bargny, S. Uganda, S. Kentucky, S. Enteritidis, and control group, respectively. In conclusion, different species of Salmonella can affect integrated duck-fish farms and cause high mortality as well as a decrease in feed intake, feed conversion ratio, and body weight gain.
\end{abstract}

Key words: Histopathology, Integrated duck-fish farms, Pathogenicity, Salmonella spp.

\section{INTRODUCTION}

Some of the fish farms are integrated with waterfowl as integrated duck-fish farms are preferred as ducks fit easily into aquaculture facilities, inducing, vegetation, pest control, and fertilization roles, in the same time this system needs minimum requirement concerning facilities and expenditure in this warm water system (Little and Edwards, 2003; Majhi, 2018). Poultry litter is used by some farms as a fertilizer due to the non-digested feed, metabolic excretory products and residues in poultry litter resulting in a microbial synthesis that can be utilized to replace reasonable parts of feedstuff used in conventional fish production cost (Bekibele and Onunkwo, 2007; Hirpo, 2017). The microbiological examination of poultry litter exhibits various pathogenic microorganisms. Existence of pathogens in litter and in the aqua-system is considered one of the critical reasons for infection transmission (Guan and Holley, 2003; Soliman et al., 2018).

The objective of the present study was to identify Salmonella species which may be present in poultry litter and can access to fish ponds during fertilization of the ponds and consequently infect ducks integrated with aquaculture. Moreover, the clinicopathological aspects of salmonellosis were evaluated by experimental infection of ducklings with isolated Salmonella.

\section{MATERIALS AND METHODS}

\section{Ethical approval}

The animal use protocol in this study approved by the Institutional Animal Care and Use Committee (Vetcu02122019102). 


\section{Experimental design and sampling}

Samples were obtained according to the research design from the different districts in Kafr El-Sheikh Governorate, Egypt. In total, 50 litter samples, 200 cloacal swabs from integrated duck farms and 69 water samples from fish ponds, 60 liver samples were taken from sacrificed ducks from different fish farms. All samples were labeled and transported to the laboratory. (Animal Health Research Institute, Kafr El-Sheikh provisional laboratory, Egypt). The samples were subjected to Salmonella isolation and identification.

\section{Isolation and identification of different Salmonella serotypes}

Isolation of different Salmonella was applied on litter. Briefly, $25 \mathrm{~g}$ of litter samples were prepared by mixing in a sterile flask with $225 \mathrm{ml}$ phosphate buffer saline (PBS, Bio Basic, Canada). Water samples obtained through inverting a $500 \mathrm{ml}$ sterilized flask in $30 \mathrm{~cm}$ (AbdElghany et al., 2015) depth water surface. Then, $30 \mathrm{ml}$ of water samples were clarified by centrifugation (centrifugeUniversal- Germany) at $5000 \mathrm{rpm}$ for 5 minutes. Cloacal swabs and liver samples (A sterile cotton swabs stabbed into liver parenchyma) by using nutrient broth (Oxoid, UK), where $1 \mathrm{ml}$ of all of these samples inoculated in nutrient broth and incubated at $37^{\circ} \mathrm{C}$ for $24 \mathrm{hr}$. Then, $1 \mathrm{ml}$ of incubated broth was inoculated into selenite $\mathrm{F}$ broth (Oxoid, UK) and incubated at $37{ }^{\circ} \mathrm{C}$ for $24 \mathrm{hr}$. a loopful from this broth were streaked onto Salmonella-shigella (SS) agar (Oxoid, UK) and incubated at $37{ }^{\circ} \mathrm{C}$ for $24 \mathrm{hr}$. All the suspected pure colonies of salmonellae were furtherly subjected to biochemical reactions (methyl-red, Voges-Proskauer, indole and urea tests) according to Cheesbrough (1985). Biochemically positive reaction for Salmonella isolates was finally identified according to (Grimont and Weill, 2007) using Salmonella poly "O" antiserum and Salmonella monovalent "O and $\mathrm{H}$ " antiserum (SINIF Co., Germany). Then a five Salmonella isolates were employed to study the clinicopathological picture in duckling.

\section{Comparative clinicopathological effects of Salmonella isolates}

Fifty, one-day-old Pekin duckling were employed to study the clinicopathological effects of the different Salmonella isolates including S. Bargny, S. Tshingwe, S. $U$ ganda, S. Kentucky and $S$. Enteritidis in susceptible oneweek-old ducklings through oral inoculation. Eight experimental ducklings were bacteriologically examined and proved to be free from Salmonella. The remaining 42 ducklings subdivided into six equal groups (1-6) by ranking methods. At the $7^{\text {th }}$ day, the first five groups were inoculated orally (using 1-ml sterile feeding tube via crop) containing ( $\left.1 \times 10{ }^{9} \mathrm{cfu}\right) /$ duckling (Barrow et al., 1999) of each of S. Bargny, S. Tshingwe, S. Uganda, S. Kentucky, and $S$. Enteritidis respectively, while the $6^{\text {th }}$ group kept as uninfected control and was similarly inoculated orally with physiological saline. Each group was reared separately in wire-floored batteries and fed on commercial ration which contain the nutritional requirement for Pekin duckling. Feed and water were given $a d . l i b$. All ducklings were kept under observation for signs and deaths up to 3 weeks of age. Cloacal swabs were collected for detection of fecal shedding from all groups during the first 3 days postinoculation (PI), then at the weekly interval at the $2^{\text {nd }}$ and the $3^{\text {rd }}$ week PI. Moreover, at the end of the $2^{\text {nd }}$ and $3^{\text {rd }}$ week, two randomly selected ducks were sacrificed from each group for postmortem, bacteriological and histopathological examination. Initial and final body weight, feed consumption, body weight gain and feed conversion rate were calculated at a weekly interval as averages. Percentages of the average values of the infected groups were also calculated relative to the average values of the uninfected control group to allow better comparison. Also Re-isolation of salmonellae from dropping, liver, spleen and gall bladder of experimentally infected sevenday-old ducklings.

\section{Statistical analysis}

The obtained numerical data were statistically analyzed using SPSS software. Duncan's multiple range test was used for testing significance of differences among group means at $\mathrm{p}$-value $<0.05$.

\section{RESULTS}

Results of salmonellae isolation are shown in table 1, which revealed that 19 Salmonella isolates were recorded from poultry litter, fish pond water, cloacal swabs of integrated ducks and liver of integrated ducks at rates of 8 , $2.9,4$ and $8.3 \%$, respectively.

All 19 Salmonella isolates were subjected to biochemical identification and the results are summarized and presented in table 2 . The biochemically identified Salmonella isolates were serologically identified by using monovalent and polyvalent "O" and "H" Salmonella antisera. Results are summarized and presented in tables 3 and 4. Nineteen Salmonella isolates included S. Kentucky 
$(\mathrm{n}=4), S$. Enteritidis $(\mathrm{n}=2), S$. Bargny $(\mathrm{n}=2)$ and one isolate for each of $S$. Belgdam, $S$. Cuckmere, $S$. Tshiongwe, $S$. Gueuletapee, $S$. Oxford, $S$. Atakpame, $S$. Ferruch, $S$. Uganda, $S$. Amsterdam, $S$. Brikama and $S$. Kulsrivier. Salmonella Kentucky was the most frequent isolate with a rate of $21 \%$, followed by $S$. Enteritidis and $S$. Bargny with a rate of $10.5 \%$. Table 4 shows that all Salmonella isolated were motile containing flagellar antigen "H" with its two phases "H1" and "H2" except $S$. Belgdam, S. Gueuletapee, S. Amsterdam and S. Enteritidis which contained "H1" only.

Table 1. Numbers and percentage of isolated salmonellae from different samples in integrated duck-fish farming

\begin{tabular}{lccc}
\hline \multirow{2}{*}{$\begin{array}{l}\text { Types of } \\
\text { samples }\end{array}$} & $\begin{array}{c}\text { Total number of } \\
\text { samples }\end{array}$ & \multicolumn{2}{c}{ Salmonella } \\
\cline { 3 - 4 } & & $\begin{array}{c}\text { Number } \\
\text { of isolates }\end{array}$ & $\%$ \\
\hline Litter samples & 69 & 2 & 2.9 \\
$\begin{array}{l}\text { Water } \\
\text { samples }\end{array}$ & 50 & 4 & 8 \\
Liver $^{\text {a }}$ & 60 & 5 & 8.3 \\
Fecal swabs ${ }^{\text {b }}$ & 200 (pooled sample) & 8 & 4 \\
Total & 379 & 19 & 5 \\
\hline $\begin{array}{l}\text { a from scarifying ducks and duckling }{ }^{b} \text { 3 pooled sample (2-3 individual } \\
\text { samples) were taken from each farm }\end{array}$
\end{tabular}

Clinical signs, postmortem findings and mortality rate during experimental infection with chosen Salmonella isolates

Clinical signs were recorded as mentioned in table 5, from this table it is clear that the clinical signs were detected in all infected groups 24-48 hours PI in the form of extreme thirst, profuse diarrhea, huddling together as chilled, ruffled feather in some of them, lameness appeared in S.Bargny. Staggering gait appeared in S.Tshingwe 24hrs PI and in S.Enteritidis $72 \mathrm{hrs}$. PI. This was followed by retraction of the head towards the chest, later by tremors, retraction of the neck backward, paddling movement, coma, and death. Gross lesions of dead and/or sacrificed birds from the five infected groups were recorded and mentioned in table 5, from this table it is clear that the gross lesions revealed severe congestion of all internal organs, enlargement of the spleen, enlargement, and lobulation of the kidney, distention of the ureters with urates and typhlitis with frothy content. $S$. Bargny and, S.Enteritidis groups appeared to have necrotic foci on liver. Also, liver appeared very pale in third week PI in each of S. Uganda, S. Kentucky, and S.Enteritidis groups. Mortality ranged from $28.6 \%$ in $S$. Bargny, $S$. Enteritidis and $S$. Kentucky and increased to $42.9 \%$ in $S$. Uganda and reached up to $100 \%$ in S.Tshingwe as mentioned and recorded in table 6 .

Also shedding pattern (Table 7), organ colonization (Table 8), initial body weight, final body weight, feed consumption, body weight gain, and feed conversion rate (Table 9) were measured and calculated.

\section{Histopathological findings in ducklings infected with salmonellae}

Generally, Salmonella infection in ducklings produced marked tissue alterations as compared to the negative control group. The main lesions were recorded in liver, spleen, and intestine. Regarding to the experimental infection by using different Salmonella species including S. Bargny, S. Tshingwe, S. Uganda, S. Kentucky, and S. Enteritidis, the histopathological finding are summarized and presented in table 10 and from this table, it is clear that the degenerative effect and necrotic effect in liver, also depletion and macrophage infiltration were more remarkable in S. Tshingwe (Figure 1) than S. Bargny (Figure 2) and S. Uganda (Figure 3) in the first week postinfection, also the degenerative effect in the liver in second week post-infection was clearer in S. Bargny (Figure 4) than S. Uganda, S. Kentucky (Figure 5) and S. Enteritidis, macrophage infiltration in spleen is clear in $S$. Bargny and S. Uganda than S. Kentucky and S. Enteritidis (Figure 6).

Also, hyperplasia in lining epithelium of examined intestine was higher in $S$. Bargny followed by $S$. Enteritidis as compared with each of $S$. Uganda and $S$. Kentucky while the histopathological changes in the third week post-infection were less remarkable than the previous weeks. Hyperplasia of the lining epithelium of examined intestine was more remarkable in cases infected with $S$. Bargny and $S$. Uganda compared to each of $S$. Kentucky and $S$. Enteritidis while enteritis was not detected in cases infected with $S$. Uganda and $S$. Kentucky.

Also, ducks infected with S. Kentucky from two weeks post-infection showed hepatic vacuolation and a mild degree of histiocytic proliferation in spleen (Figure 7). 
Table 2. Biochemical characters of isolated Salmonella from different samples in integrated duck-fish farming

\begin{tabular}{|c|c|c|c|c|c|c|c|c|c|}
\hline \multirow{2}{*}{ Items } & \multirow{2}{*}{ Motility } & \multirow{2}{*}{ Indole } & \multirow{2}{*}{ M.R } & \multirow{2}{*}{ V.P } & \multicolumn{4}{|c|}{ TSI } & \multirow{2}{*}{ urea } \\
\hline & & & & & $\mathrm{H}_{2} \mathrm{~S}$ & gas & Butt & slant & \\
\hline Salmonella isolates & + & - & + & - & + & + & $\mathrm{Y}$ & $\mathrm{R}$ & - \\
\hline
\end{tabular}

M.R: methyl red. V.P: Voges-Proskauer. TSI: triple sugar iron. $\mathrm{H}_{2} \mathrm{~S}$ : hydrogen sulfide. The samples used were poultry litter samples and water samples from fish farms as well as cloacal swabs and liver samples from ducks.

Table 3. Serotypes of isolated Salmonella from different samples in integrated duck-fish farming

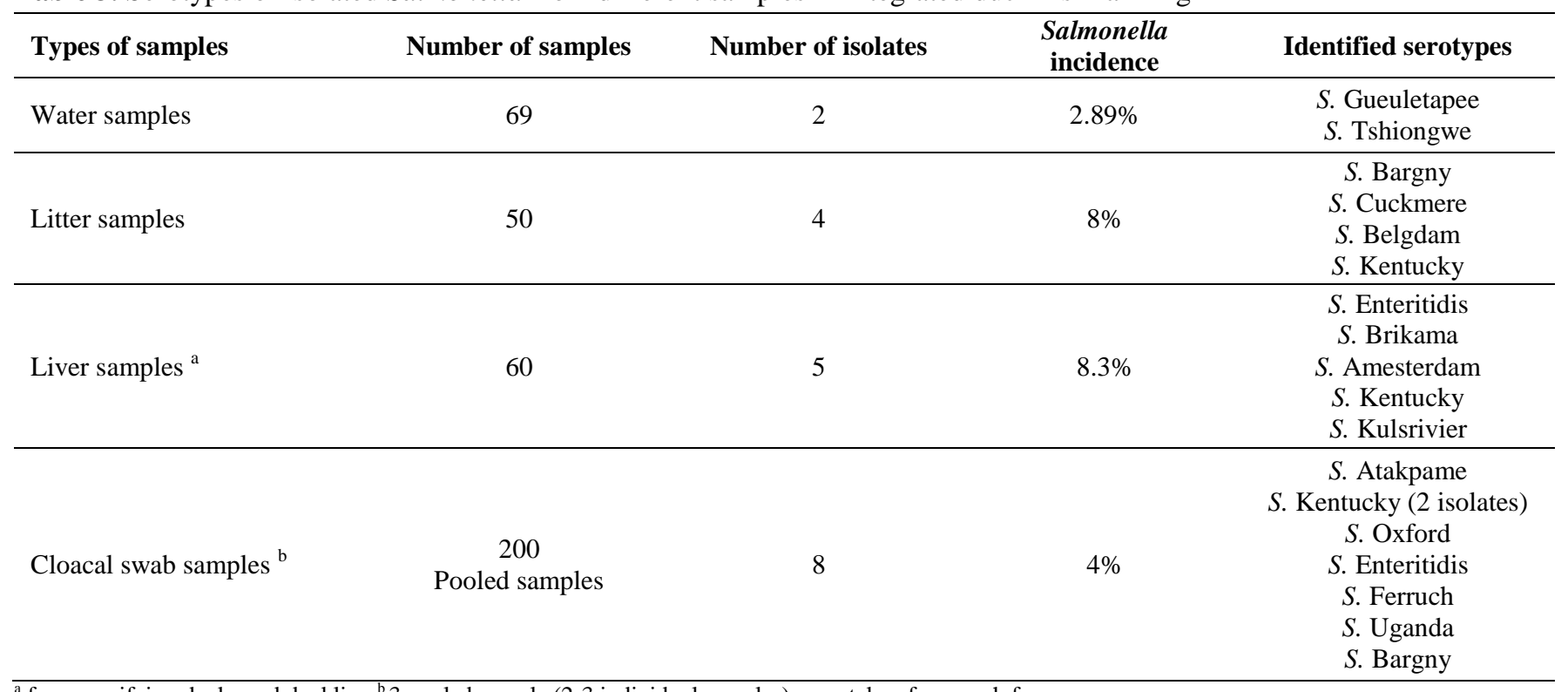

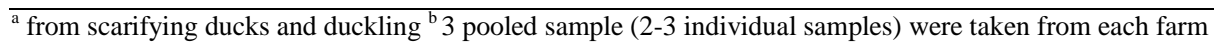

Table 4. Antigenic profile of isolated Salmonella from different samples in integrated duck-fish farming

\begin{tabular}{|c|c|c|c|}
\hline \multirow{3}{*}{ Serotype } & \multicolumn{3}{|c|}{ Antigenic structure profile } \\
\hline & \multirow{2}{*}{$O$ antigen } & \multicolumn{2}{|c|}{$H$ antigen } \\
\hline & & Phase I & Phase II \\
\hline S. Bargny & 8,20 & 1 & 1,5 \\
\hline$S$. Brikama & 8,20 & $\mathrm{r}, \mathrm{i}$ & $1, \mathrm{w}$ \\
\hline S. Tshiongwe & 6,8 & $\mathrm{e}, \mathrm{h}$ & e,n,z15 \\
\hline S. Uganda & $3,10,(15)$ & $1, \mathrm{Z} 13$ & 15 \\
\hline S. Belgdam & 9,46 & $\mathrm{~g}, \mathrm{~m}, \mathrm{q}$ & - \\
\hline S. Atakpame & 8,20 & $\mathrm{e}, \mathrm{h}$ & 1,7 \\
\hline S. Gueuletapee & $1,9,12$ & $\mathrm{~g}, \mathrm{~m}, \mathrm{~s}$ & - \\
\hline S. Oxford & $3,10,(15),(15,34)$ & A & 1,7 \\
\hline S. Kentucky & 8,20 & I & Z6 \\
\hline
\end{tabular}


Table 5. Clinical signs and postmortem lesions in experimentally infected 7-day-old ducks with different Salmonella serovars.

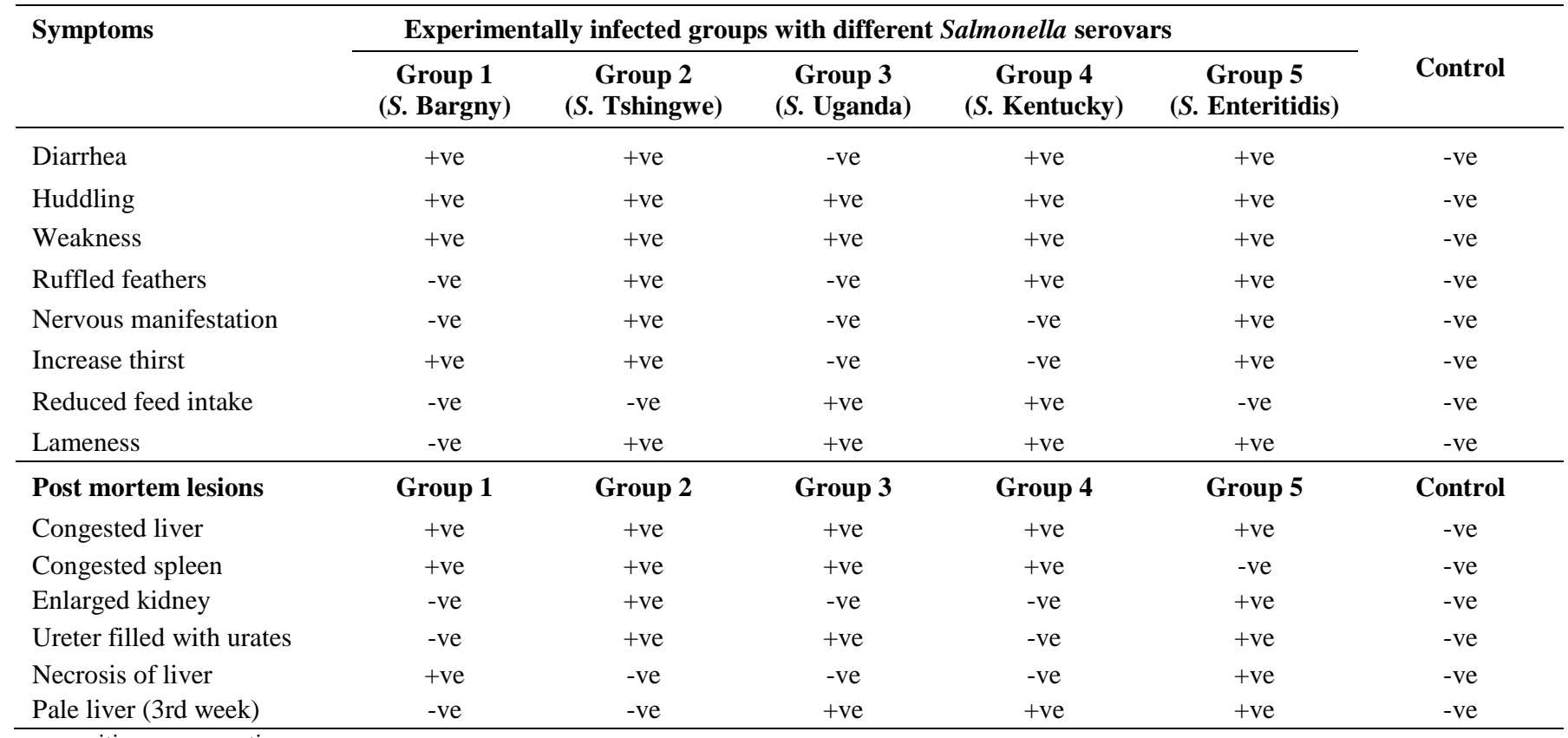

+ve: positive. -ve: negative.

Table 6. Mortality pattern and mortality rate in experimentally infected 7-day-old ducks with different Salmonella serovars.

\begin{tabular}{|c|c|c|c|c|c|c|c|}
\hline \multirow{2}{*}{$\mathrm{P}_{\text {Groups }}$ Time } & \multicolumn{4}{|c|}{ 1st week } & \multirow[b]{2}{*}{ 2nd week } & \multirow[b]{2}{*}{ 3rd week } & \multirow[b]{2}{*}{ Mortality rate } \\
\hline & 1st day & 2nd day & 3rd day & 4th day & & & \\
\hline Group 1 (S.Bargny) & 1 & - & 1 & - & 2 (sacrified) & 2 (sacrified) & $28.6 \%$ \\
\hline Group 3 (S.Uganda) & - & 1 & 1 & 1 & 2 (sacrified) & 2 (sacrified) & $42.9 \%$ \\
\hline Group 4 (S.Kentucky) & - & - & 1 & 1 & 2 (sacrified) & 2 (sacrified) & $28.6 \%$ \\
\hline Control group & - & - & - & - & 2 (sacrified) & 2 (sacrified) & $0 \%$ \\
\hline
\end{tabular}

Table 7. Duration of fecal Salmonella shedding in experimentally infected ducks with different Salmonella serovars

\begin{tabular}{|c|c|c|c|c|c|c|c|c|c|c|c|c|c|c|c|c|}
\hline Shedding & \multicolumn{3}{|c|}{$\begin{array}{c}\text { Group 1 } \\
\text { (S. Bargny) }\end{array}$} & \multicolumn{3}{|c|}{$\begin{array}{c}\text { Group 2 } \\
\text { (S. Tshingwe) }\end{array}$} & \multicolumn{3}{|c|}{$\begin{array}{c}\text { Group } 3 \\
\text { (S. Uganda) }\end{array}$} & \multicolumn{3}{|c|}{$\begin{array}{c}\text { Group 4 } \\
(S . \text { Kentucky) }\end{array}$} & \multicolumn{3}{|c|}{$\begin{array}{c}\text { Group 5 } \\
(S . \text { Enteritidis })\end{array}$} & $\begin{array}{c}\text { Contro } \\
+\mathrm{ve}\end{array}$ \\
\hline Second day & 2 & 6 & 33 & 4 & 6 & 66.6 & 2 & 7 & 28.6 & 3 & 7 & 42.9 & 1 & 7 & 14.3 & 0 \\
\hline Third day & 1 & 6 & 16.6 & 1 & 4 & 25 & 2 & 6 & 33.3 & 2 & 7 & 28.6 & 3 & 6 & 50 & 0 \\
\hline $\begin{array}{l}\text { Second } \\
\text { week }\end{array}$ & 2 & 5 & 40 & - & - & - & 1 & 4 & 25 & 2 & 5 & 40 & 1 & 5 & 20 & 0 \\
\hline Third week & 3 & 3 & 100 & - & - & - & 1 & 2 & 50 & 2 & 3 & 66.6 & 1 & 3 & 33.3 & 0 \\
\hline Total & 12 & 27 & 44.4 & 8 & 18 & 44.4 & 10 & 27 & 37.4 & 11 & 30 & 36.6 & 8 & 29 & 27.5 & 0 \\
\hline
\end{tabular}

*cloacal swabs collected in $4^{\text {th }}$ day post-infection only from dead ducks. + ve: positive. $\quad$-ve: negative 
Table 8. Recovery of Salmonella from different organs of freshly dead and /or sacrificed ducks after oral experimental infection with different Salmonella serovars

\begin{tabular}{|c|c|c|c|c|c|c|c|c|c|c|c|c|c|}
\hline \multirow[t]{2}{*}{ Organ } & \multicolumn{2}{|c|}{$\begin{array}{c}\text { Group 1 } \\
\text { (S. Bargny) }\end{array}$} & \multicolumn{2}{|c|}{$\begin{array}{c}\text { Group 2 } \\
\text { (S. Tshingwe) }\end{array}$} & \multicolumn{2}{|c|}{$\begin{array}{c}\text { Group } 3 \\
(S . \text { Uganda) }\end{array}$} & \multicolumn{2}{|c|}{$\begin{array}{c}\text { Group } 4 \\
(S . \text { Kentucky) }\end{array}$} & \multicolumn{2}{|c|}{$\begin{array}{c}\text { Group 5 } \\
\text { (S. Enteritidis) }\end{array}$} & \multirow{2}{*}{$\begin{array}{c}\text { Control } \\
\text { No. }\end{array}$} & \multicolumn{2}{|c|}{ Total } \\
\hline & No. & $\%$ & No. & $\%$ & No. & $\%$ & No. & $\%$ & No. & $\%$ & & No. & $\%$ \\
\hline Liver & $3 / 6$ & 50 & $3 / 7$ & 42.9 & $2 / 7$ & 28.6 & $2 / 6$ & 33 & $2 / 6$ & 33 & - & $12 / 32$ & 37.5 \\
\hline Spleen & $3 / 6$ & 50 & $4 / 7$ & 57.1 & $4 / 7$ & 57.1 & $3 / 6$ & 50 & $4 / 6$ & 66.7 & - & $18 / 32$ & 56.2 \\
\hline Gall bladder & $2 / 6$ & 33.3 & $2 / 7$ & 28.6 & $3 / 7$ & 28.6 & $1 / 6$ & 16.6 & $2 / 6$ & 33 & - & $10 / 32$ & 31.2 \\
\hline Heart blood & $2 / 6$ & 33.3 & $2 / 7$ & 28.6 & $2 / 7$ & 28.6 & $1 / 6$ & 16.6 & $1 / 6$ & 16.6 & - & $8 / 32$ & 25 \\
\hline Total & 10 & 41.7 & 11 & 39.3 & 11 & 39.3 & 7 & 29.2 & 9 & 37.5 & - & & \\
\hline
\end{tabular}

Table 9. Performance analysis of seven-day-old duckling under Salmonella infection

\begin{tabular}{|c|c|c|c|c|c|c|}
\hline $\begin{array}{ll}\text { Parameters } & \text { Groups } \\
\end{array}$ & $\begin{array}{c}\text { Group 1 } \\
(S . \text { Bargny })\end{array}$ & $\begin{array}{c}\text { Group 2 } \\
(S . \text { Tshingwe }) \\
\end{array}$ & $\begin{array}{c}\text { Group } 3 \\
\text { (S. Uganda) }\end{array}$ & $\begin{array}{c}\text { Group } 4 \\
(S . \text { Kentucky) } \\
\end{array}$ & $\begin{array}{c}\text { Group 5 } \\
(S . \text { Enteritidis }) \\
\end{array}$ & Control \\
\hline Initial body weight $(\mathrm{g} ; \mathrm{M} \pm \mathrm{SE})$ & $170 \pm 5.3$ & $172 \pm 5.7$ & $172 \pm 5.5$ & $170 \pm 6.2$ & $171.71 \pm 6.8$ & $173 \pm 8.7$ \\
\hline Relative average final body weight $(\%)$ & 81 & 0 & 88 & 86.5 & 80 & 100 \\
\hline Relative average body weight gain $(\%)$ & 68.6 & 0 & 79.8 & 78.1 & 66.5 & 100 \\
\hline Feed intake $(\mathrm{g})$ & 846 & 0 & 986 & 941 & 829 & 972 \\
\hline Relative average feed intake $(\%)$ & 87 & 0 & 101.4 & 96.8 & 85.5 & 100 \\
\hline Feed conversion ratio & 5.1 & 0 & 5.11 & 4.98 & 5.15 & 4.02 \\
\hline
\end{tabular}

Table 10. Semi-quantitative assessment of the histopathological score in experimentally infected ducks with different Salmonella serovars

\begin{tabular}{|c|c|c|c|c|c|c|c|}
\hline \multirow[b]{2}{*}{ Isolates } & \multirow{2}{*}{$\begin{array}{l}\text { Sampling time } \\
\text { (week post- } \\
\text { infection ) }\end{array}$} & \multicolumn{2}{|c|}{ Liver } & \multicolumn{2}{|c|}{ Spleen } & \multicolumn{2}{|c|}{ Intestine } \\
\hline & & Degeneration & Necrosis & $\begin{array}{l}\text { Lymphoid } \\
\text { depletion }\end{array}$ & $\begin{array}{l}\text { Macrophage } \\
\text { infiltration }\end{array}$ & Enteritis & $\begin{array}{l}\text { Hyperplasia of the } \\
\text { lining epithelium }\end{array}$ \\
\hline$S$.Tshingwe & 1 & ++++ & ++++ & ++++ & +++ & & \\
\hline S.Uganda & 1 & +++ & ++ & ++ & +++ & & \\
\hline S.Bargny & 2 & +++ & ++ & ++ & +++ & ++ & ++++ \\
\hline S.Kentucky & 2 & ++ & + & + & ++ & + & ++ \\
\hline S.Enteritidis & 2 & ++ & + & + & ++ & + & +++ \\
\hline S.Bargny & 3 & ++ & + & + & ++ & + & ++ \\
\hline S.Uganda & 3 & ++ & + & + & ++ & + & ++ \\
\hline S.Kentucky & 3 & ++ & Not detected & Not detected & ++ & Not detected & + \\
\hline
\end{tabular}

+ mild, ++ moderate ,+++ severe focal and ++++ severe diffuse lesions 


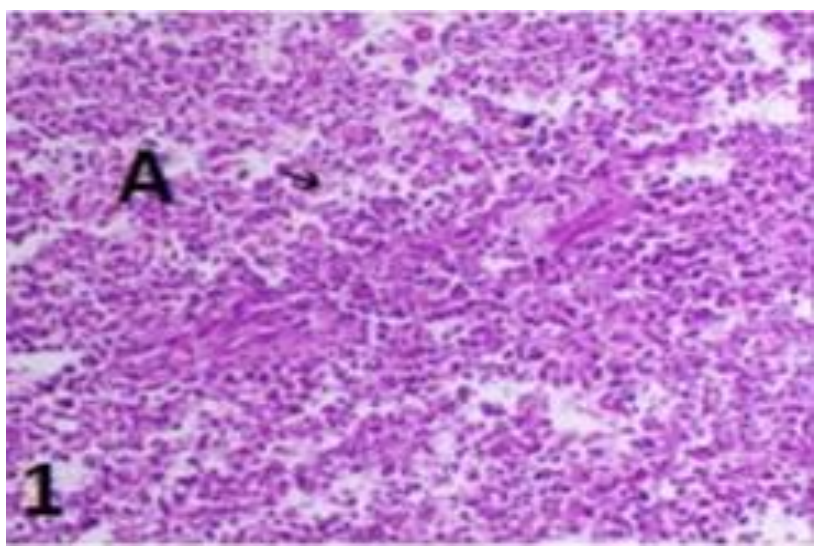

Figure 1. Diffuse necrosis of the lymphoid tissue mostly of liquefactive type (arrow A) in spleen of ducklings infected with Salmonella Tshingwe and sacrificed 7 days post-infection.

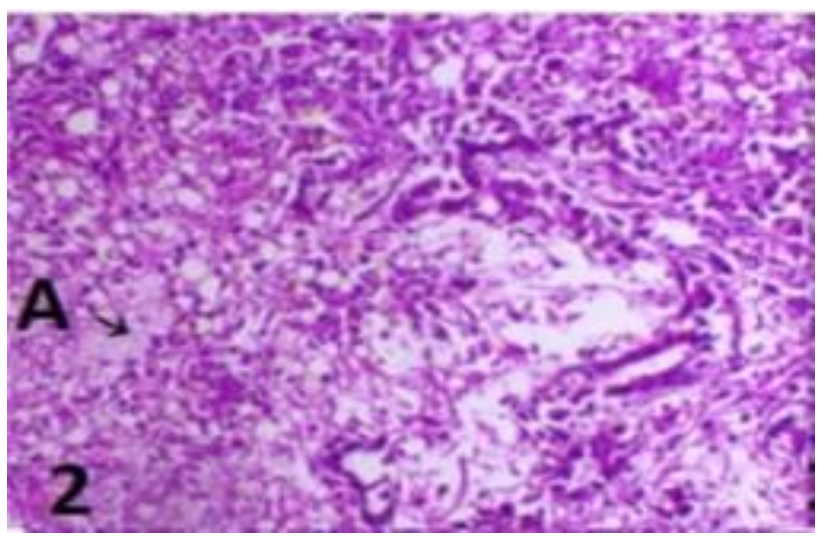

Figure 2. Large necrotic foci (arrow A) in liver of ducklings infected with Salmonella Bargny and sacrificed 7 days post-infection.

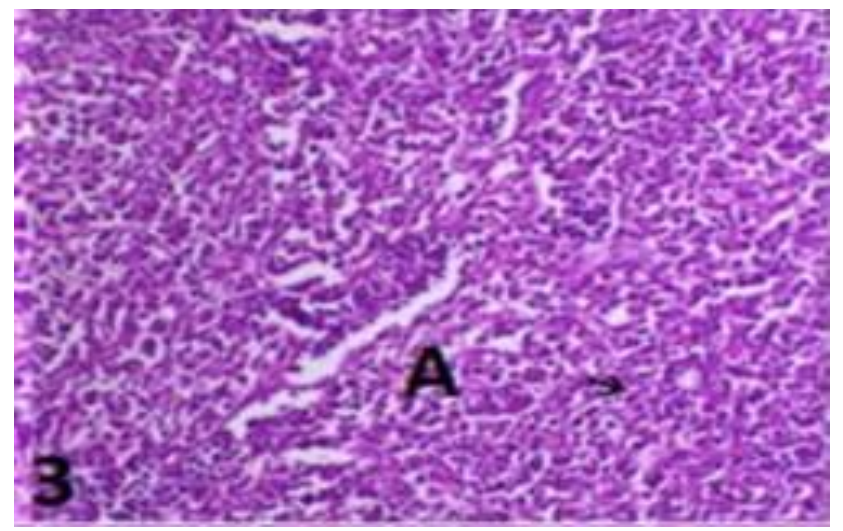

Figure 3. Lymphoid depletion associated with increase the inflammatory cell infiltration within the splenic parenchyma (arrow A) in spleen of ducklings infected with Salmonella Uganda and sacrificed 7 days postinfectionn

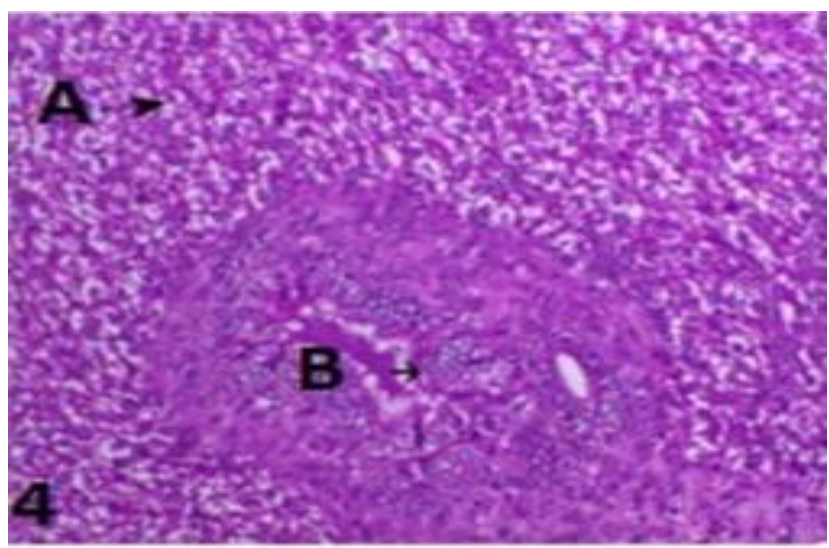

Figure 4. vacuolation of hepatocytes (arrow A) associated with bile duct lining epithelium hyperplasia (arrow B) in liver of ducklings infected with Salmonella Bargny and sacrificed 2 weeks post-infection.

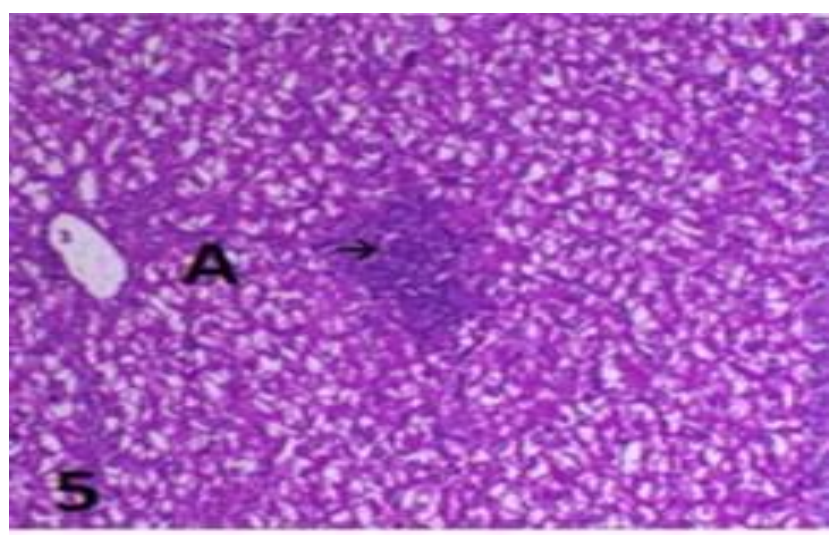

Figure 5. Mononuclear cells infiltration consisted mainly of lymphocytes and macrophages (arrows) and diffuse vacuolation of hepatocytes in liver of ducklings infected with Salmonella Kentucky and sacrificed 2 weeks post-infection.

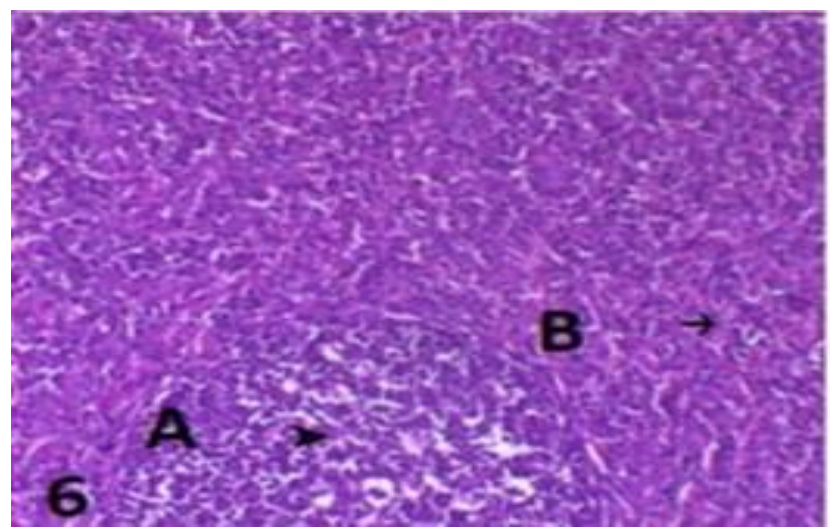

Figure 6. Mild degree of lymphoid depletion (arrow A) and minimal macrophages infiltration (arrow B) in spleen of ducklings infected with Salmonella Enteritidis and sacrificed 2 weeks post-infection. 


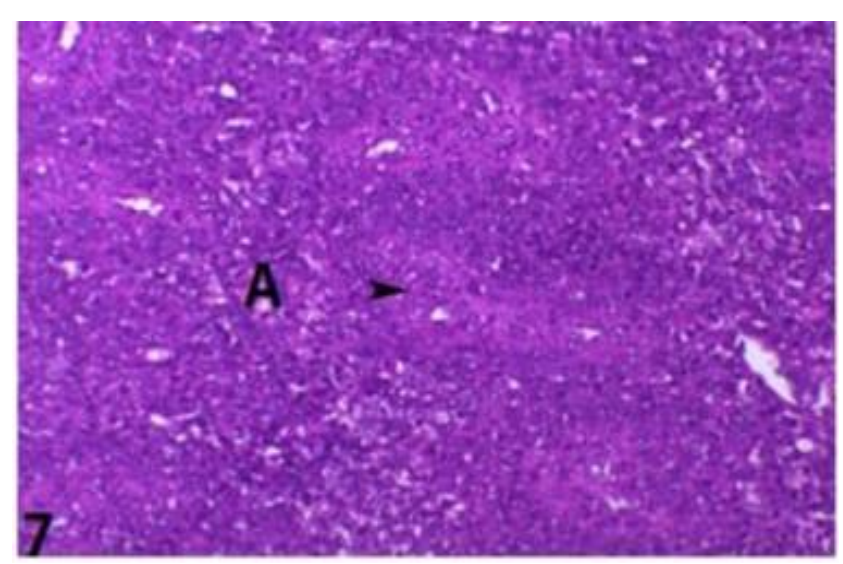

Figure 7. Perivascular histiocytic and macrophages infiltration (arrow A) in spleen of ducklings infected with Salmonella Kentucky and sacrificed 3 weeks postinfection.

\section{DISCUSSION}

Transmission of Salmonella species to waterfowls can be mediated by contaminated feeds, water, and litter (Gast 2003; Grigar et al., 2017). In the present work, Salmonella was isolated from litter with a rate of $8 \%$, this rate appears to be higher than that previously reported in Egypt by Dahshan et al. (2015) who reported a rate of $4 \%$. However, Rusul et al. (1996) reported that the isolation rate of Salmonella from broiler litter was $20 \%$ also Abunna et al. (2016) reported Salmonella from poultry litter with a rate of $40 \%$. The recorded high rates of Salmonella in poultry litter in this study may be due to the different epidemiological picture of Salmonella infection and its shedding in poultry farms in governorates that integrated with fish farms breeding and waterfowls production $8 \%$ rather than other governorates with less integrated fish production and this indicates the role of integrated waterfowls and fish farms of the incidence and distribution of Salmonella infection and its ecological impact, also the unhygienic measurement in small-scale poultry farms in Kafr El-Sheikh Governorate and it poses a critical point for Salmonella transmission to fish farms in the integrated systems because the large scale farms are under veterinary supervision.

Salmonella spp. can be reached to aqua-system by fecal contamination and it has been reported in freshwater fish culture ponds in many countries and also may be present naturally in tropical aquatic environments (Musefiu et al., 2011; Lotfy et al., 2011).

In the present study, salmonellae were isolated from ducks cloacal swabs with a rate of $4 \%$ (8 out of 200 pooled samples). This percent is lower than that reported by Mondal et al. (2008) who examined 65 fecal swabs from ducks and reported Salmonella with a rate $13.07 \%$ but it is higher than that reported by Hegazy (1991) who isolate Salmonella from cloacal swabs of ducks and duckling with incidence $0.98 \%$ and $0.72 \%$ respectively.

Salmonellae have the ability to multiply and survive in internal organs particularly spleen and liver because these organs can provide places where bacterial multiplication can arise without interruption by host defense mechanism (Gast, 2003). Liver showed Salmonella isolation with an incidence of $8.3 \%$. Many authors succeeded to isolate Salmonella from liver with a more or less identical incidence as Badr et al. (2015) reported four Salmonella isolates from the liver of ducks with a percentage of $6.45 \%$. Also, this incidence is nearly similar to that isolated by Selvaraj et al. (2010) from poultry in India with incidence $(6.25 \%)$. However, it was lower than that reported in Egypt by Abd-Elghany et al. (2015) who reported Salmonella from the chicken liver with an incidence of $32 \%$.

In this study, a total of 13 Salmonella isolates were obtained from duck farms integrated with fish farms (200 cloacal swabs and 60 liver samples) with incidence (5\%) but this percent is lower than that reported by Lebdah et al., (2017) from ducks in Dakahlia and Damietta Governorates in Egypt with a rate (11.7\%), (Mahmoud and Moussa, 2000) reported 25 positive samples for Salmonella out of 125 samples from 10 duck flocks in North Sinai with $20 \%$ rate.

Salmonella Uganda isolated from ducks in this study with a rate of $7.7 \%$ and this may be the first report of $S$. Uganda isolation from ducks in Egypt according to the available literature. This serovar was predominantly isolated from pigs and it was responsible for 4 porkassociated outbreaks in humans between 1998 and 2008 in the USA (Jackson et al., 2013).

In this study, the mortality ranged from $28.6 \%$ in $S$. Bargny, $S$. Enteritidis, and $S$. Kentucky and increased to $42.9 \%$ in S.Uganda and reached up to $100 \%$ in $S$. Tshingwe. there is no report about the mortality rate of some of these serotypes according to the available literature, however, Osman et al., (2010) reported the mortality of $S$.Enteritidis in chicken with a rate $88 \%$ also they reported the mortality in case of $S$. Kentucky with a rate 40\%. Hegazy (1991) reported mortalities from $S$. Enteritidis from ducklings with a rate of $10 \%$ while no mortalities were reported in $S$. Tshingwe infected group. In agreement with another investigator, Copper et al., (1992) and Barrow (2000) the postmortem lesions in dead and/or sacrificed ducks generally included congestion of 
internal organs, enlargement of spleen, typhlitis and distention of ureter with urates.

Experimental Salmonella infection resulted in changes in feed consumption, body weight, and feed conversion. The relative average feed consumption for the infected groups was $13 \%,-1.4 \%, 3.2 \%$ and $14.5 \%$ for $S$. Bargny, S. Uganda, S. Kentucky, and S. Enteritidis, respectively with missing the data belonging to S.Tshingwe because the mortality in this group reached to $100 \%$ in the first $48 \mathrm{hr}$. relative average body weight was also affected and showed a reduction ranged from $20.2 \%$ to $33.5 \%$ among the infected groups at the end of the experiment. These data are in a general agreement with those reported by Levine and Graham (1942) and Williams (1978).

The histopathological picture was in general agreement with that described by several investigators for paratyphoid infection in ducks as El-Sawy, (1976) and chicken as Habib-ur-Rehman et al., (2003) and Haider et al., (2004). However, it is interesting to note that liver degeneration and necrosis with lymphoid depletion and macrophage infiltration were more severe in case of $S$. Tshingwe and this may explain the high mortalities that reached to $100 \%$ among this group.

\section{CONCLUSION}

Integrated duck farms can be infected with different species of Salmonella, which cause high mortality, reduced feed consumption and feed conversion ratio as well as decreased body weight gain. These consequences lead to negative economic impact, particularly when associated with high mortality. Therefore, salmonellosis in integrated duck farms should be investigated periodically.

\section{DECLARATIONS}

\section{Competing interests}

The authors have no competing interests

\section{Acknowledgment}

We are thankful to Animal Health Research Institute in Dokki and its provisional lab in Kafr El-Sheikh governorate and also to the department of poultry diseases in the faculty of veterinary medicine at Cairo University for the validation, equipment and the laboratory where this research was performed and completed.

\section{Authors' contribution}

Anwaar Mettwally El-Nabarawy contributed in planning, interpretation, and revision of the research, Mohamed Abdel Salaam Shakal design the idea for the research, Abdel-Haleem Mohamed Hegazy contributed in following up adoption of methodology and Mohamed Mohamed Ismail Batikh contributed through performing technical works including sampling, isolation and identification, experimental infection, collecting data and data analysis. All authors approved the final manuscript.

\section{REFERENCES}

Abd-Elghany S, Sallam K, Abd-Elkhalek A and Tamura T (2015). Occurrence, genetic characterization and antimicrobial resistance of Salmonella isolated from chicken meat and giblets. Epidemiology and Infection, 143: 9971003. DOI: https://doi.org/10.1017/S0950268814001708

Abunna F, Bedasa M, BeyeneT, Ayana D , Mamo B and Duguma R (2016). Salmonella: isolation and antimicrobial susceptibility tests on isolates collected from poultry farms in and around Modjo, Central Oromia, and Ethiopia. Journal of Animal and Poultry Sciences, 5(2), 21-35. Available at : https://pdfs.semanticscholar.org/910c/b1351e0787b8961861 52a28843a97be1d367.pdf

Badr H, Rahman M, Farghaly M, Gaber A, Roshdy H and Nasef S. A (2015). Characterization of some aerobic bacterial microorganism isolated from newly hatched imported ducklings. Egyptian Poultry Science Journal, 35: 11231136. Available at: $\underline{\text { Link }}$

BARROW P (2000). The paratyphoid salmonellae. Revue Scientifique et Technique-Office International des Epizooties, 19: 351-366. Available at: https://pdfs.semanticscholar.org/40f5/6a3b7a83a2421611a4 ade58c418584f7b445.pdf.

Barrow P, Lovell M, Murphy C and Page K (1999). Salmonella infection in a commercial line of ducks; experimental studies on virulence, intestinal colonization and immune protection. Epidemiology \& Infection, 123: 121-132 Available at: https://www.ncbi.nlm.nih.gov/pmc/articles/PMC2810735/p df/10487648.pdf.

Bekibele D and Onunkwo D (2007). Economic benefit and ecological efficiency of integrated fish farming in Nigeria. Scientific Research and Essays, 2: 302-308. Available at: http://www.academicjournals.org/app/webroot/article/article 1380271056_Gabriel\%20et\%20al.pdf.

Cheesbrough M (1985). Medical Laboratory Manual for Tropical Countries. Vol. 2. Microbiology. pp. 400-480.

Copper GL, Venables LM, NICHOLAS RA, Cullen G A and Hormaeche CE (1992). Vaccination of chickens with chicken-derived Salmonella Enteritidis phage type 4 aroA live oral Salmonella vaccines. Vaccine, 10: 247-254. DOI: https://doi.org/10.1016/0264-410X(92)90160-L. 
Dahshan H, Abd-elall AMM, Megahed AM, ABD-EL-KADER MA and Nabawy EE (2015). Veterinary antibiotic resistance, residues, and ecological risks in environmental samples obtained from poultry farms, Egypt. Environmental Monitoring and Assessment, 187:2. DOI: https://doi.org/10.1007/s10661-014-4218-3.

El-Sawy E (1976): studies on salmonellosis in ducks. M.V.Sc. Thesis Faculty of Veterinary Medicine Cairo University.

Gast RK (2003): Paratyphoid infection in: Diseases of poultry, 11th edition. (Editors Saif,Y.). Iwa State University Press, Ames. pp. 583-613.

Grigar MK, Cummings KJ and Rankin SC (2017). Prevalence of Salmonella among waterfowl along the Texas Gulf coast. Zoonoses and Public Health, 64(8): 689-692. DOI: https://doi.org/10.1111/zph.12380

Grimont PA and Weill FX (2007). Antigenic formulae of the Salmonella serovars. WHO Collaborating Centre for Reference and Research on Salmonella, 9: 1-166

Guan TY and Holley RA (2003). Pathogen survival in swine manure environments and transmission of human enteric illness, a review. Journal of Environmental Quality, 32: 383392 DOI: https://doi.org/10.2134/jeq2003.3830.

Habib-ur-rehman S, Khan H, Khan S, Ahmad N and Bhatti WM (2003). Incidence and gross pathology of salmonellosis in chicken in Hyderabad. Journal of Animal and Veterinary Advances. Available at: http://docsdrive.com/pdfs/medwelljournals/javaa/2003/581584.pdf.

Haider M, Hossain M, Hossain M, Chowdhury E, Das P and Hossain M (2004). Isolation and characterization of enterobacteria associated with health and disease in Sonali chickens. Bangladesh Journal of Veterinary Medicine, 2: 15-21. Available at: https://www.banglajol.info/index.php/BJVM/article/downlo ad/1928/1815.

Hegazy AM (1991). Studies on Salmonella infections in ducks. M.V.SC. thesis. Faculty of Veterinary Medicine Cairo University.

Hirpo LA (2017). Evaluation of integrated poultry-fishhorticulture production in Arsi Zone, Ethiopia. International Journal of Fisheries and Aquatic Studies, 25: 562-565. Available https://pdfs.semanticscholar.org/8665/daf57c4f0015ea1c4e4 cec42c04563ed36e7.pdf

Jackson BR, Griffin PM, Cole D, Walsh KA and Chai SJ (2013). Outbreak-associated Salmonella enterica serotypes and food commodities, United States, 1998-2008. Emerging Infectious Diseases, 19: 1239. DOI: https://doi.org/10.3201/eid1908.121511.

Lebdah MA, Eid AA, Nasef SA and Hamad EM (2017). Phenotypic and genotypic characterization of paratyphoid Salmonellae isolated from poultry in Delta Area-Egypt. Zagazig Veterinary Journal, 45(3), 262-272. DOI: https://doi.org/10.5281/zenodo.999713.
Levine N and Graham R (1942). Paratyphoid in baby wood ducks. Journal of American Veterinary Medical Association, 100: 240-41. Link

Little D and Edwards P (2003). Integrated livestock-fish farming systems. Food and Agriculture Organiation. Link

Lotfy NM, Hassanein M, Abdel-gawad F, El-taweel G and Bassem S (2011). Detection of Salmonella spp. in aquatic insects, fish and water by MPN-PCR. World Journal of Fish and Marine Sciences, 3: 58-66.

Mahmoud A and Moussa H (2000). Bacteriological and histopathological studies on Salmonella isolates from ducks in North Sinai. Egyptian Journal of Agricultural Research, 78: 15-24. Available at: https://www.cabdirect.org/cabdirect/abstract/20013148120.

Majhi A (2018). integrated duck cum fish farming management for socio economic ufliftment and poverty alleviation of rural people in Purulia District, West Bengal. International Journal of Pure and Applied Bioscience, 6(6): 653-661. DOI: http://dx.doi.org/10.18782/2320-7051.6868.

Mondal T, Khan M, Alam M, Purakayastha M, Das M and Siddique M (2008). Isolation, identification and characterization of Salmonella from duck. Bangladesh Journal of Veterinary Medicine, 6: 7-12. Available at: https://www.banglajol.info/index.php/BJVM/article/downlo $\mathrm{ad} / 1331 / 1319$

Musefiu T, Obuko E and Bolarinwa A (2011). Isolation and identification of aerobic bacteria flora of the skin and stomach of wild and cultured Clarias gariepinus and Oreochromis niloticus from Ibadan, Southwest Nigeria. Journal of Applied Sciences Research, 7: 1047-1051. DOI: https://doi.org/10.1016/0168-1605(96)01125-7.

Osman KM, Moussa IM and Yousuf A (2010). Pathogenicity of some avian Salmonella serovars in two different animal models: SPF-chickens and BALB/C mice. Environment \& We an International Journal of Science and Technology, 5: 65-78. Available at: https://www.researchgate.net/profile/Moustafa_Radwan2/pu blication/228519150_Pathogenicity_of_some_avian_Salmo nella serovars in two different animal models SPF chic kens_and_BALBc_mice/links/571f287b08aed056fa227b4b/ Pathogenicity-of-some-avian-Salmonella-serovars-in-twodifferent-animal-models-SPF-chickens-and-BALB-cmice.pdf.

Rusul G, Khair J, Radu S, Cheah C and Yassin RM (1996). Prevalence of Salmonella in broilers at retail outlets, processing plants and farms in Malaysia. International Journal of Food Microbiology, 33: 183-194. DOI: https://doi.org/10.1016/0168-1605(96)01125-7.

Selvaraj R, Das R, Ganguly S, Ganguli M, Dhanalakshmi S and Mukhopadhayay S (2010). Characterization and antibiogram of Salmonella spp. from poultry specimens. Journal of Microbiology and Antimicrobials, 2: 123-126. Available at : http://www.academicjournals.org/JMA.

Soliman ES, Sallam NH, and Abouelhassan EM (2018). Effectiveness of poultry litter amendments on bacterial survival and Eimeria oocyst sporulation. Veterinary World, 11(8): 1064. DOI: https://doi.org/10.14202/vetworld.2018.1064-1073 
Williams JE (1978). Paratyphoid infection. In: Diseases of Poultry. (Editors Hofstad, M.S. Calnek, B.W. Helmboldt,
C.F. Reid, W.M. and Yoden, H.W). Iowa State University Press. Ames. 